\section{断面構成が異なる耐火集成材柱 の燃焼特性}

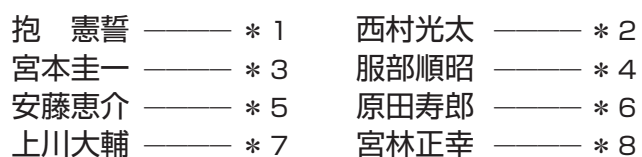

キーワード

耐火集成材，柱，スギ，カラマツ，インサイジング処理，燃焼性状， 耐火試験

\section{Keywords:}

Fire-preventive glued laminated timber, Column, Cedar, Larch, Incising treatment, Burning behaviour, Fire resistance test

\begin{tabular}{|c|c|c|}
\hline Norichika KAKAE- & $* 1$ & Kouta NISHIMURA \\
\hline Keiicl & $* 3$ & Nobuaki HATTORI \\
\hline Keis & $* 5$ & Toshiro HARADA - \\
\hline aisuke KAMIK & $* 7$ & Masayuki MIYABAYASHI - \\
\hline
\end{tabular}

The Japanese government is promoting use of wood in recent years, because of the environmental provision of carbon dioxide fixation. The authors developed "FR wood". "FR wood" is the only technique with simply use one tree species in Japan. "FR wood" is built by three layers. The central member supports load, the second layer prevents a fire and the third layer is surface. A lot of experimental cases were conducted, and many temperature data or carbonization thickness data were accumulated. The measured maximum temperature depended on the thickness and the tree species of load supporting member.

\section{1.はじめに}

国内では，森林資源の有効活用や炭素固定化による $\mathrm{CO}_{2}$ 削減など を目的として木材利用が促進されている。建築分野でも, 内装材や 構造体一の木材利用が進んでいる。しかし，防火地域や準防火地域 では，建物規模が大きくなると耐火構造が求められるため，可燃物 である木材で耐火性能を実現する，様々な研究が行われている。木 材周辺を石膏ボードなどの不燃材で覆ったり，熱容量が高い材料を 配したりして温度上昇を抑制する対策が採られている ${ }^{1) ~ 3) 。 ~}$

筆者らは，1 時間耐火構造を目指して国産スギ材のみを利用した 耐火集成材を開発し，大断面と小断面の 2 種類の部材で国土交通大 臣認定を取得した ${ }^{45)}$ )。断面構成は図 1 に示寸ように，無処理の木 材で構成した荷重支持部，火災からの火熱の侵入を防ぐ燃え止まり 層，および化粧材からなる三層としている。これらにより，燃え止 まり層に必要な仕様を把握できたことから，燃え止まり層の厚さを 規定して, 大断面部材から小断面部材の範囲のなかで荷重支持部を 自由に設定することが可能となった。

断面を構成する三層のうち，荷重支持部である無処理のスギ集成 材を加熱から守るため，第二層に燃え止まり層を配置する。燃え止 まり層のスギのラミナには難燃薬剤を含浸させ，熱の侵入を遮り酸 素を断つことで燃え止まりを実現する。難燃薬剤には，木材の難燃 化処理剂として実績のある窒素リン酸系の薬剤を使用した。また, 難燃薬剤をラミナ内に均一に含浸させるため，集成材を構成するラ
ミナには穴あけ処理（以降，インサイジング処理）を施した。最外 層には, 難燃薬棛流出を抑える目的と共に化粧材としての役割をす るスギの無処理層を配置した。

本研究では，国土交通大臣認定を取得した断面を基本として，荷 重支持部の大きさや燃え止まり層の厚さ, 荷重支持部の樹種を因子 とした耐火試験を実施し，保護すべき荷重支持部と燃え止まり層境 界における温度性状や燃え止まり層の炭化性状の確認を行ったので 報告する。

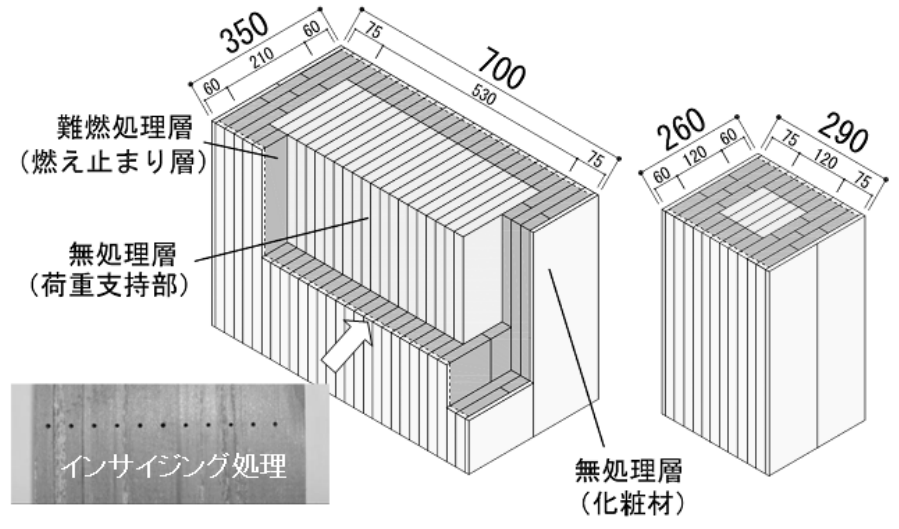

大断面 小断面 単位 $[\mathrm{mm}]$

図 1 耐火集成材の概念図

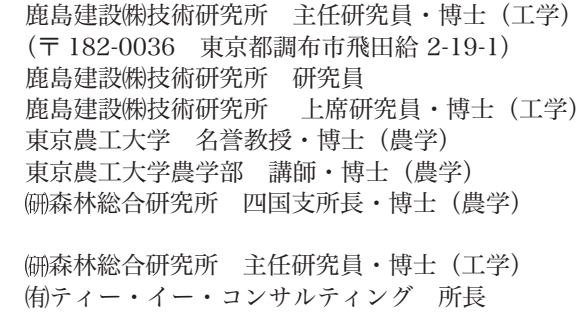

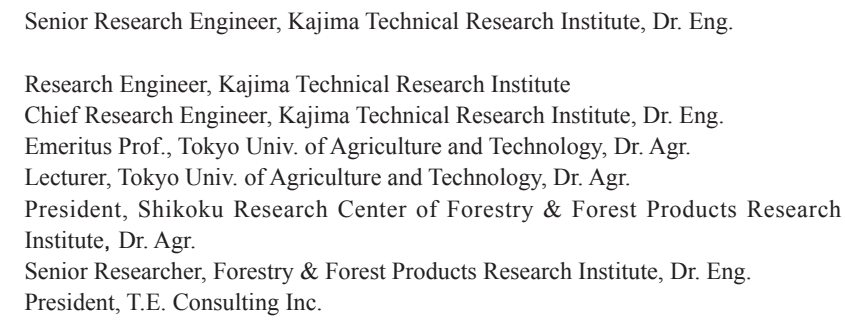


表 1 試験体の断面構成および試験条件

\begin{tabular}{|c|c|c|c|c|c|c|}
\hline & 試験体 I & 試験体 II & 試験体 III & 試験体IV & 試験体 V & 試験体VI \\
\hline 断面寸法 [mm] & $350 \times 700$ & $300 \times 600$ & $260 \times 290$ & $2220 \times 220$ & $240 \times 240$ & $240 \times 240$ \\
\hline 荷重支持部寸法 [mm] & $210 \times 530$ & $180 \times 480$ & $120 \times 120$ & $120 \times 120$ & $120 \times 120$ & $120 \times 120$ \\
\hline 荷重支持部樹種 & スギ & スギ & スギ & カラマツ & スギ & カラマツ \\
\hline 化粧材厚 $[\mathrm{mm}]$ & 10 & 10 & 10 & 10 & 10 & 10 \\
\hline 平均薬剂注入量 $\left[\mathrm{kg} / \mathrm{m}^{3}\right]$ & 158 & 156 & 165 & 142 & 138 & 138 \\
\hline 加熱範囲長 [mm] & 3000 & 3000 & 3000 & 1500 & 2000 & 2000 \\
\hline 載荷軸力 [kN] & 635 & 434 & 40.9 & 0 & 0 & 0 \\
\hline 試験場所 & \multicolumn{3}{|c|}{ （一財） 建材試験センター } & \multicolumn{3}{|c|}{ 鹿島技術研究所 } \\
\hline
\end{tabular}

*表中の (巾)は巾はぎ方向，（積）は積層方向を示す

\section{2. 耐火試験}

\section{1 試験体}

本研究では, 6 体の異なる試験体を製作し, 耐火試験を実施した。 各試験体の断面構成を表 1 に示す。試験体 I および試験体III は国土 交通大臣認定を取得した基本断面であり, 荷重支持部（スギ，密度 $320 \sim 330 \mathrm{~kg} / \mathrm{m}^{3}$, 含水率 : 9. 3 12\%）の寸法のみが異なる。また燃 え止まり層厚（密度： $480 \sim 510 \mathrm{~kg} / \mathrm{m}^{3}$ ，含水率：11.2 14.2\%）は, 図 1 に示したように厚い方向 (積層方向) と薄い方向 (巾はぎ方向) の 2 種類ある。これに対して試験体 II と試験体 V は, 同じ荷重支持 部樹種（スギ）で, 荷重支持部寸法および然え止まり層厚を基本断 面から変更した。また, 試験体IVおよび試験体VIはさらに荷重支持 部樹種（カラマツ）および然え止まり層厚を変更した。燃え止まり 層には，窒素リン酸系の難燃薬剤を平均的に含浸寸るため，インサ イジング処理を施したラミナを使用した。インサイジング処理では, 各ラミナに孔径 $1.5 \mathrm{~mm}$ の穴を貫通させた。各ラミナの接着には, レ ゾルシノール系樹脂接着剤を用いた。各燃え止まり層に含浸させた 難燃処理薬剤の平均含浸量は, $138 \sim 165 \mathrm{~kg} / \mathrm{m}^{3}$ である。また温度計測 用に，荷重支持部と燃え止まり層境界の隅角部および辺中央部（一

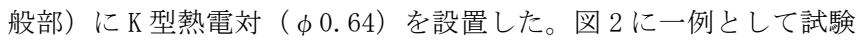
体 $\mathrm{V}$ の熱電対設置位置を示す。

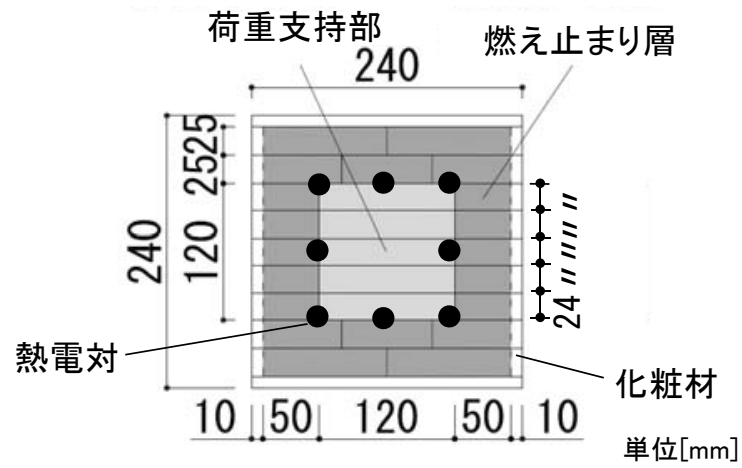

図 2 断面構成と熱電対設置位置（試験体 $\mathrm{V}$, 中断面）

\section{2 試験条件}

試験は，(一財）建材試験センターの柱炉および鹿島技術研究所の 兼用炉で実施した。IS0834 標準加熱曲線 ${ }^{6)}$ に従い 1 時間加熱し, 加 熱終了後炉内に 11 時間放置した。試験終了時に火気残存がないこと を目視で確認した後, 放水冷却した。後日, 脱炉後に炭化層を除去 し, 切断した断面の炭化状況を確認した。試験体設置状況を図 3 お よび写真 1 に示す。鹿島技術研究所で実施した柱試験体は離隔 $800 \mathrm{~mm}$ で設置したが，過去の試験において試験体間の相互放射の影響で燃

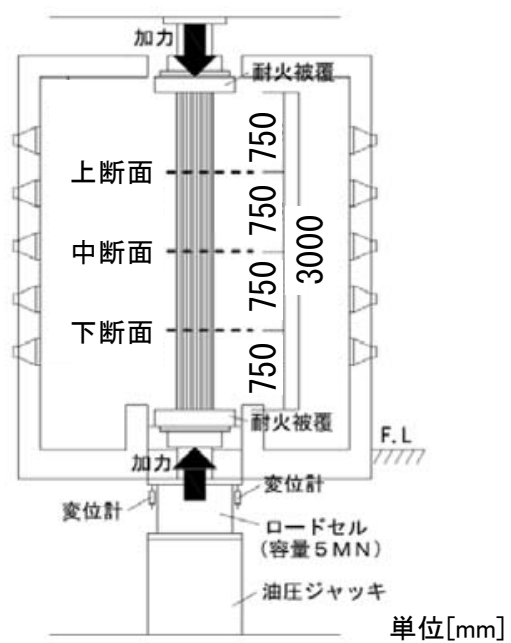

図 3 試験体設置状況（(一財）建材試験センター)

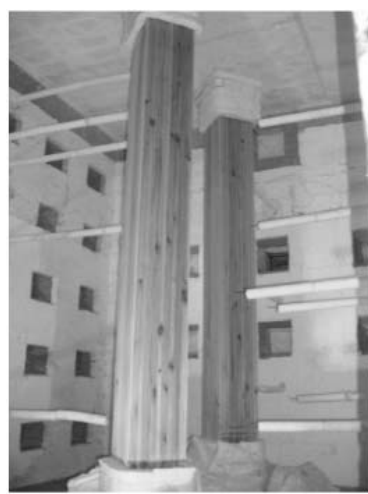

写真 1 試験体設置状況（鹿島技術研究所）

焼が激しくなり正対面で温度上昇が大きくなることはなかった。ま た試験範囲外からの熱侵入・燃え込みを防ぐため，（一財）建材試験 センター試験体（試験体 I 〜試験体III）では上下端の鋼板をセラミ ックファイバーブランケットで, 鹿島技術研究所試験体（試験体IV 〜試験体VI）では上下端を石こうボードとセラミックファイバーブ ランケットで被覆した。

\section{3. 試験結果}

\section{1 加熱温度履歴}

炉内の温度履歴を図 4 に示す。試験体 I と試験体III は同条件で 2 度の試験を行った。図より，IS0834 曲線に従って1時間の加熱が的 確に行えているが，加熱後の冷却曲線は，試験炉によって異なって いることが分かる。すなわち，鹿島技術研究所の兼用炉（試験体IV 〜試験体VI)の方が建材試験センターの柱炉(試験体 I 〜試験体 III) 
より冷却が早い。これは, 炉内の容積に起因するものと考えられる。 炉の容積が大きい場合, 試験体と炉壁との距離が大きくなり, 再放 射の影響が小さくなるため温度が低くなると推測される。また同じ 炉で実施した結果を比較すると, 試験体 I および試験体 II に比べて 試験体IIIIの温度低下が遅いことが確認される。試験体III は, 試験体 I および試験体 II に比べて荷重支持部の断面積が小さく, 熱容量が 小さいために全体的に温度低下が遅くなったと推測される。この現 象は, 各試験体の温度履歴と比較して後述する。

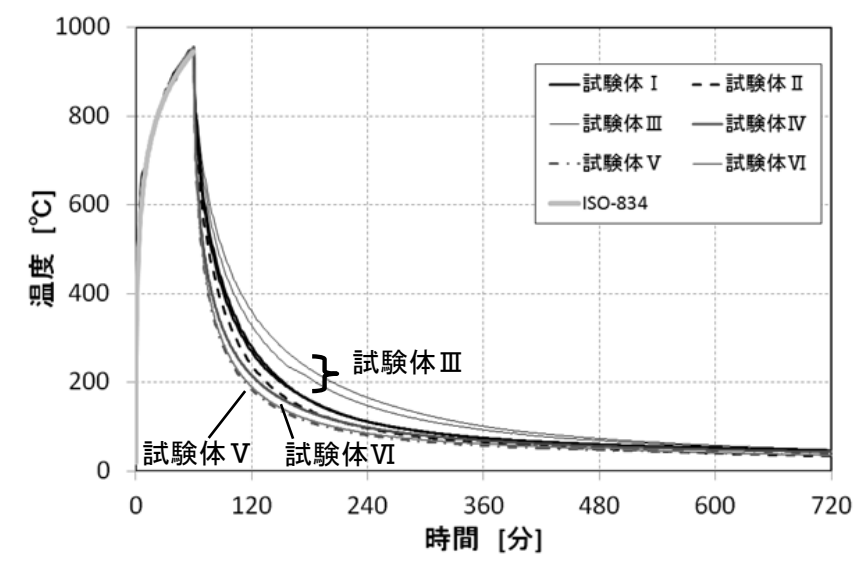

図 4 炉内の温度履歴

\section{2 試験体温度履歴}

各試験体における温度履歴に関する結果を, 図 5〜図 10 に示す。 各図中の実線は荷重支持部と燃え止まり層境界における隅角部の温. 度, 破線は一般部（辺中央部の境界測定点）の温度を示している。 各図より, 2 方向からの加熱の影響を受ける隅角部の温度が, 一般 部に比べて高温となっている。また全ての試験体において, 木材の 炭化温度とされる $260^{\circ} \mathrm{C}^{7)}$ に到達することはなかった。

燃え止まり層厚が等しい試験体 I （図 5）と試験体III（図 7）を比 較すると, 荷重支持部の断面が大きい試験体 I において最高温度が 低くなっている。試験体无では隅角部において $150^{\circ} \mathrm{C} に$ 達している のに対し, 試験体 I では熱容量の関係で $135^{\circ} \mathrm{C}$ となっている。断面 寸法が等しい試験体V（図 9）と試験体VI（図 10）では, 若干試験 体VIの方が最高温度および全体的な温度が低くなっている。試験体 VIは荷重支持部の樹種がカラマッであり, 荷重支持部がスギの試験 体 V に比べて熱容量の関係で有利となった。

一方, 最小断面である試験体IV（図 8）では, 隅角部における最 高温度が $250^{\circ} \mathrm{C}$ に迫り, 本耐火集成材の限界断面寸法であると推測 される。荷重支持部がカラマツで, 燃え止まり層厚が $10 \mathrm{~mm}$ 厚い試験 体VI と比較すると, 温度抑制効果が約 $100^{\circ} \mathrm{C}$ 生じている。

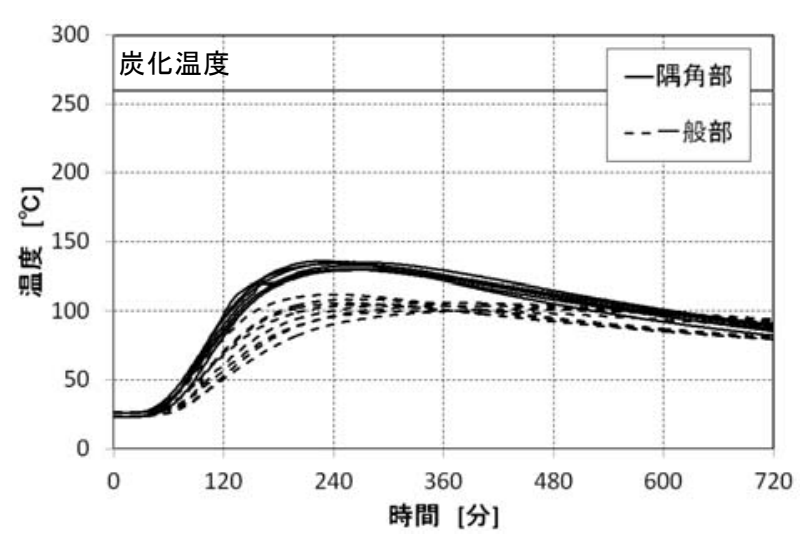

図 5 温度履歴（試験体 I ）

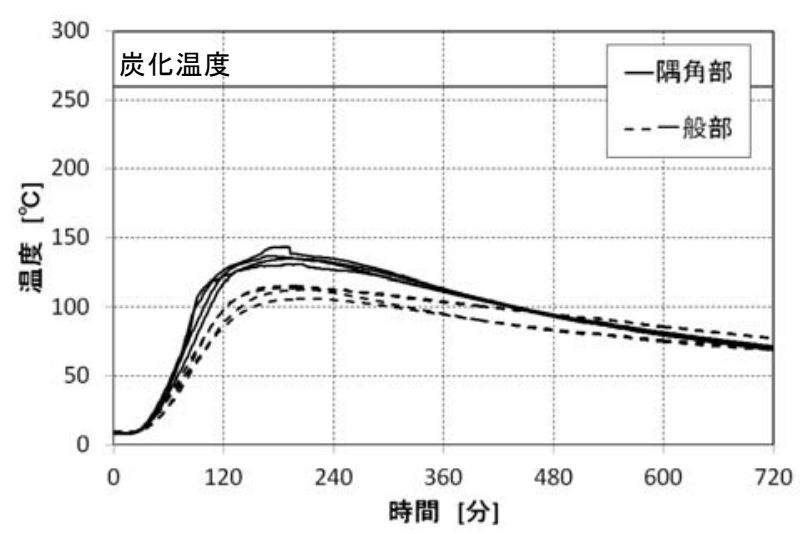

図 6 温度履歴（試験体 II）

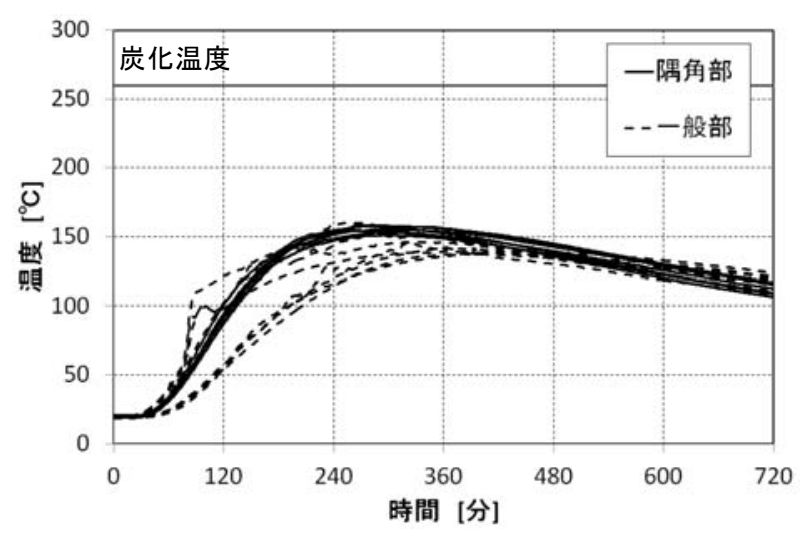

図 7 温度履歴（試験体 III）

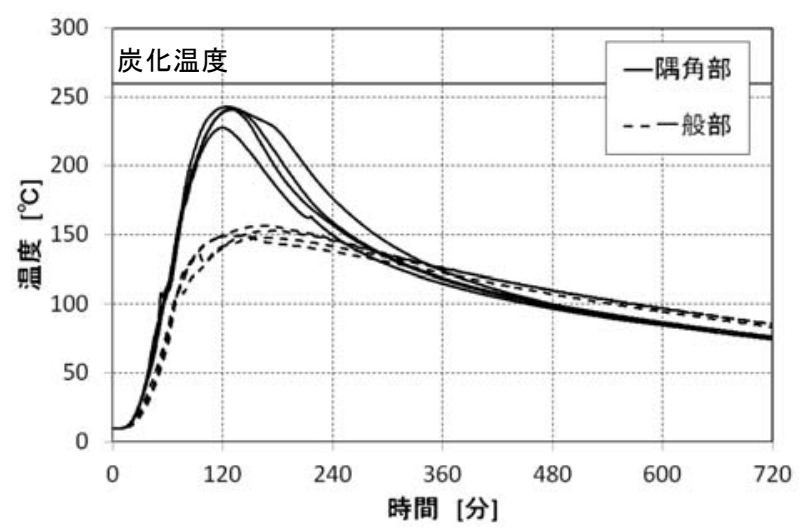

図 8 温度履歴（試験体IV） 


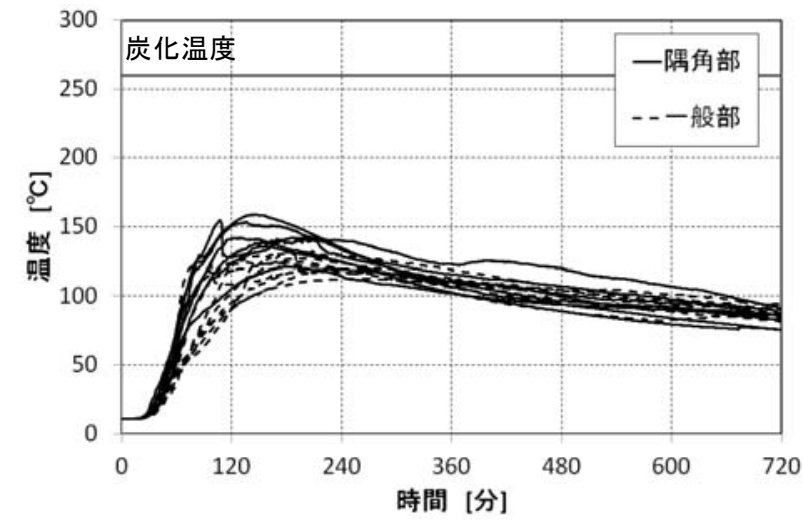

図 9 温度履歴 (試験体 $\mathrm{V}$ )

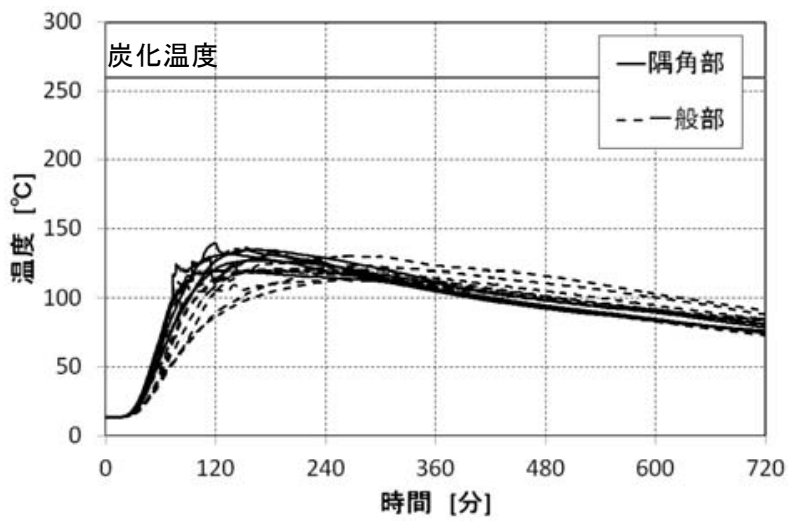

図 10 温度履歴（試験体VI）

\section{3 炭化深さ}

化粧材および難燃処理薬剤を含浸させた燃え止まり層は温度上昇 に伴い炭化する。写真 2 に示すように, 試験体表面には炭化層が形 成され, 写真 3 に示寸ように炭化層を削り取り, 積層方向に対して は中央で，巾はぎ方向では各ラミナ毎に炭化深さを計測すると図 11 の結果が得られた。図より, 燃え止まり層の厚さが薄いほど最大炭 化深さが深くなっていることが確認される。また燃え止まり層厚が 同じ条件で，熱容量が大きい場合（荷重支持部の断面が大きい，も しくは荷重支持部の樹種がカラマツ）には平均炭化深さが浅くなる 傾向となった。この傾向は, 図 5〜図 10 に示した温度履歴と同様で あり, 温度に対応して燃え止まり層が炭化していることが確認され た。また,長方形断面における短辺と長辺に明確な差異はなかった。

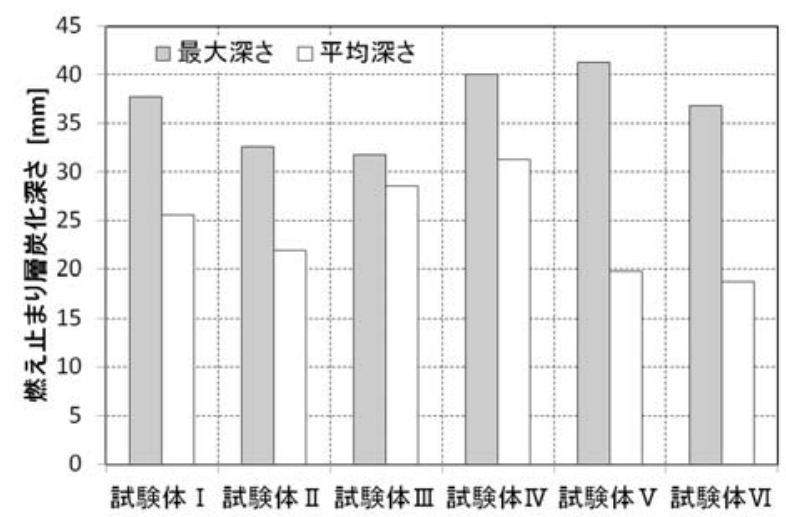

図 11 燃え止まり層の炭化深さ

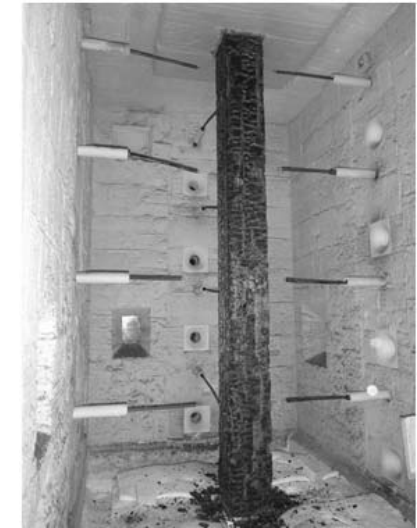

写真 2 脱炉前試験体（試験体III）

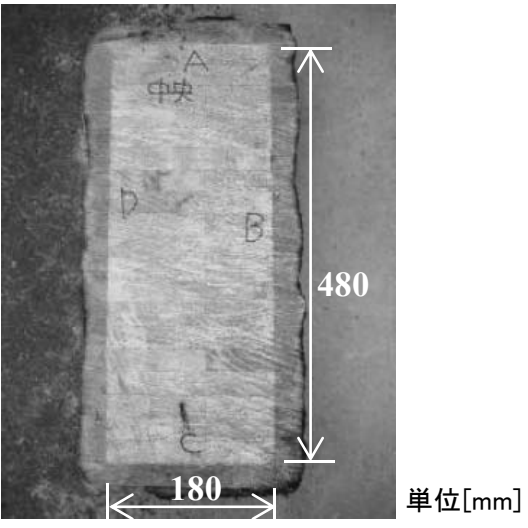

写真 3 試験後断面（試験体 II）

\section{4. 考察}

試験結果より，燃え止まり層が厚くなると荷重支持部および燃え 止まり層境界部の温度が低くなるとともに, 炭化深さも浅くなった。 燃え止まり層厚と温度性状の相互関係を確認寸るために，各試験で 得られた最高温度と, 燃え止まり層厚との関係を考察する。各距離 を図 12 に示すように定義する。図 5〜図 10 に示したように，加熱 の影響で隅角部の温度は一般部より高温となっている。そこで, 隅 角部の代表長さとして，燃え止まり層の隅角から荷重支持部隅角ま での距離を $D_{l}$, 一般部の代表長さとして, 短辺および長辺の燃え止 まり層厚を $D_{2}, D_{3}$ とする。ただし，化粧層厚は $10 \mathrm{~mm}$ に限られる。

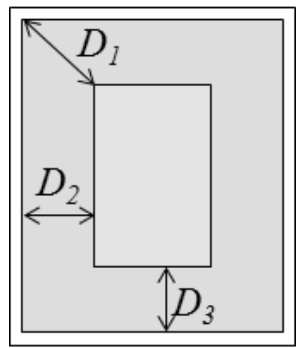

図 12 各変数の定義

\section{1 隅角部}

図 13 に隅角部における距離 $D_{l}$ と各試験における最高温度の関係 を示す。全体的な傾向は, $D_{I}=60 \mathrm{~mm}$ 付近を境として大きく変化した。 
$D_{1}$ が $60 \mathrm{~mm}$ より大い場合には最高温度が約 $150^{\circ} \mathrm{C}$ 以下であるのに対 し, $60 \mathrm{~mm}$ より小さい場合には急激に最高温度が高くなり $250^{\circ} \mathrm{C}$ 程度 となった。

$D_{I}=95 \mathrm{~mm}$ の試験体 I と試験体 III を比較すると, 燃え止まり層厚お よび荷重支持部の樹種が同じで，荷重支持部の断面積が大きく熱容 量が大きい試験体 I の方が最高温度は低くなった。 $D_{l}=70 \mathrm{~mm}$ の試験 体 V（荷重支持部スギ）と試験体VI（荷重支持部カラマツ）を比較 すると, 断面寸法が同じであるがカラマツは熱容量が大きいために， 試験体VIの方が最高温度は低くなった。また, 燃え止まり層厚およ び荷重支持部の樹種が同じで荷重支持部の断面積が大きい試験体 II は，試験体 $\mathrm{V}$ に比べて最高温度は低くなっている。

\section{2 一般部}

一般部における距離 $D_{2}, D_{3}$ と最高温度の関係を図 14 に示す。図 13 と図 14 を比較すると, 加熱の影響が主に一方向になる一般部の 最高温度の方が, 隅角部に比べて全体的に低くなった。また, 長方 形断面の場合には，燃え止まり層が厚い $\left(D_{3}\right)$ ほど最高温度が低く なっている。また， $D_{1}$ に比べて $D_{2}, D_{3}$ に対する最高温度の距離依 存性は緩やかである。正方形断面の試験体IV〜試験体VIでは，燃え 止まり層厚が等しいため, $20^{\circ} \mathrm{C}$ 弱のバラツキ幅の中に各試験結果が 収まっている。荷重支持部の樹種が異なる試験体 Vと試験体VIを比 較すると, 試験体VIの方が最高温度は低くなった。隅角部と同様に, 熱容量の大きいカラマツが荷重支持部の試験体は，炭化深さが浅く 安全側の結果を示すことが確認された。

\section{3 炭化深さ}

図 15 および図 16 に, 巾はぎ方向ではラミナ毎で, 積層方向では 面中央で計測した炭化深さの分布を示す。図より，局所的に炭化し やすいもしくは炭化しにくいラミナはあるものの，全体的には平均 值付近にまとまっている。これは, ラミナ内部における難然処理薬 剂の含浸分布に依存していると推測される。天然素材でもともとバ ラツキの大きい木材に対して, インサイジング処理を施して難然処 理薬剤を含浸させる手法を用いることでバラツキ幅を制御すること ができたと考えられる。また断面が大きい試験体 I （図 15）と小さ い試験体III（図 16）を比較すると, 全体的な傾向に差はないものの, 熱容量に起因して小断面の方が炭化深さは深い。以上より，以降で は炭化深さの平均值を代表值として試験体の炭化深さの傾向を考察 する。

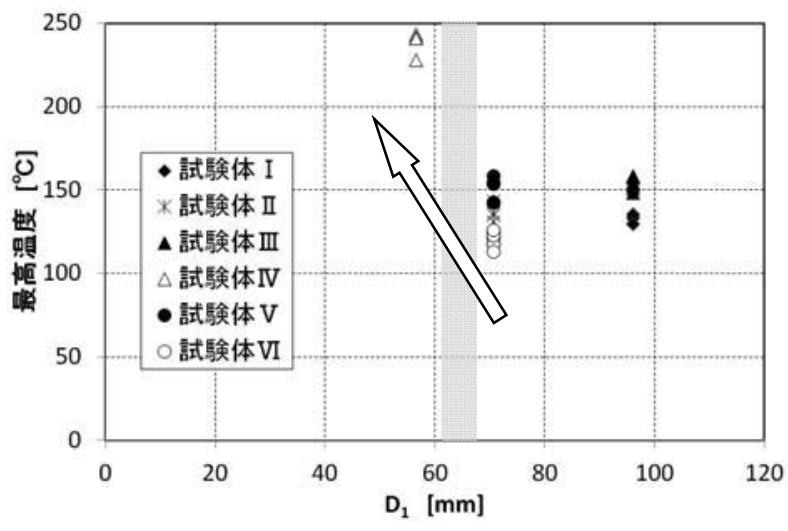

図 $13 D_{l}$ と最高温度の関係（隅角部）

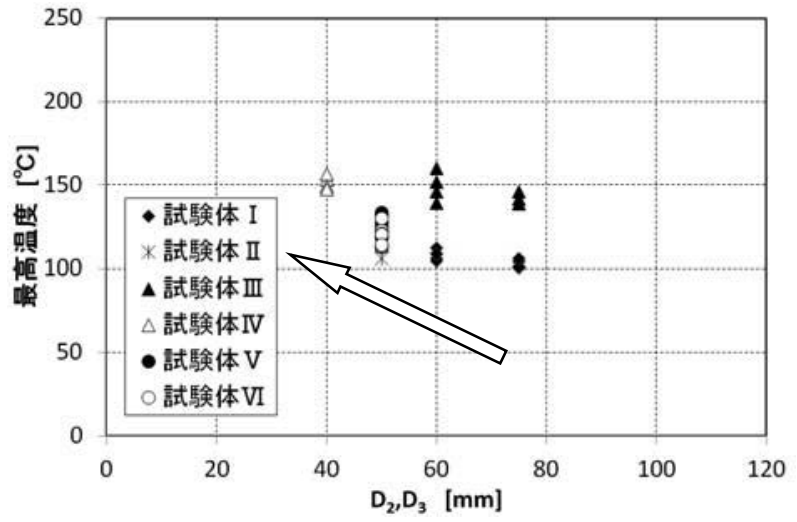

図 $14 D_{2}, D_{3}$ と最高温度の関係 (一般部)

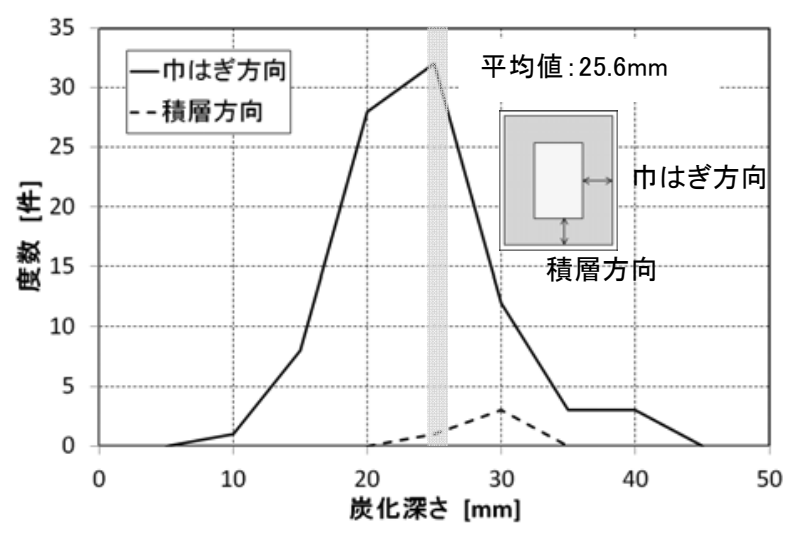

図 15 炭化深さの分布（試験体 I ）

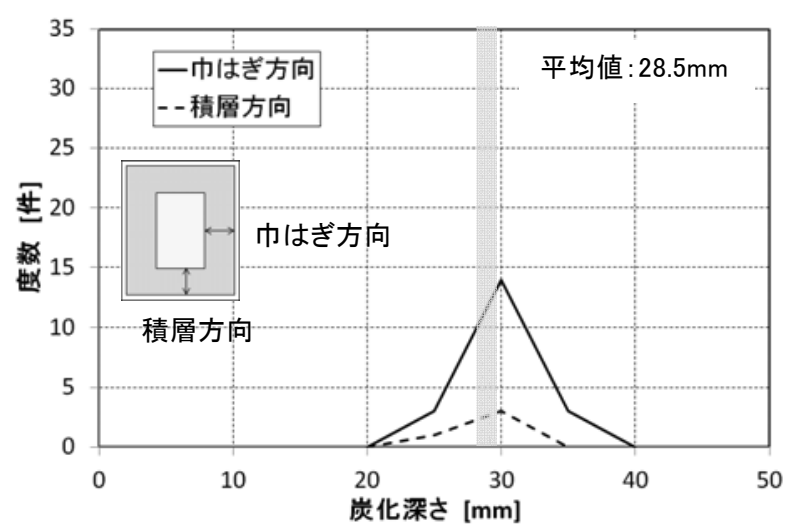

図 16 炭化深さの分布（試験体 III）

荷重支持部と燃え止まり層境界部における計測点全体の平均温度 と平均炭化深さの関係を図 17 に示す。全体的な傾向としては, 平均 温度の増加に伴い平均炭化深さも増大していることが確認される。 燃え止まり層厚毎にデータを見ると, 燃え止まり層が $40 \mathrm{~mm}$ (化粧材 含めて $50 \mathrm{~mm}$ ）では然え止まり層の炭化深さが $30 \mathrm{~mm}$ を超えて平均温 度が約 $200^{\circ} \mathrm{C}$ まで昇している。この関係からも, 燃え止まり層 $40 \mathrm{~mm}$ は荷重支持部が炭化しない最低に近い厚さであると考えられる。木 材自身が有する密度等のバラツキや難然処理薬剤の注入ムラを考慮 すると，本耐火集成材では荷重支持部の外側に燃え止まり層が $40 \mathrm{~mm}$ (化粧材含めて $50 \mathrm{~mm}$ ) に安全率を見た被覆層が必要であると考えら れる。 
燃え止まり層 $50 \mathrm{~mm}$ では, 平均温度が約 $130^{\circ} \mathrm{C} て ゙$ 然え止まり層の平 均炭化深さも約 $20 \mathrm{~mm}$ となり, 燃え止まり層 $40 \mathrm{~mm}$ に比べて約 $10 \mathrm{~mm}$ 炭化深さが浅くなった。一方, 試験体 I および試験体III では, 燃え 止まり層が $60 \mathrm{~mm}$ および $75 \mathrm{~mm}$ と厚いにも関わらず, 炭化深さが $25 \mathrm{~mm}$ 〜30mm と燃え止まり層 $50 \mathrm{~mm}$ に比べて深くなった。この原因は, 加 熱停止後の炉内の温度低下が関係していると推測される。図 5 に示 したように, 試験体IIIの加熱停止後の炉内温度は, 他の試験体に比 べて温度低下が緩やかとなった。このため, 試験体III では熱分解が 継続し, 炭化深さが深くなったと推測される。また, 図 6〜図 11 に 示したように, 最高温度に到達した後, 荷重支持部と燃え止まり層 の境界部温度は, 試験体III で温度低下が緩やかになっていることか らも加熱停止後の炉内の温度低下が影響を与えていることが裏付け られる。

断面の仕様もさることながら, 加熱停止後の炉内温度の低下勾配 も，燃え止まり性状に影響を及ぼす可能性が確認された。

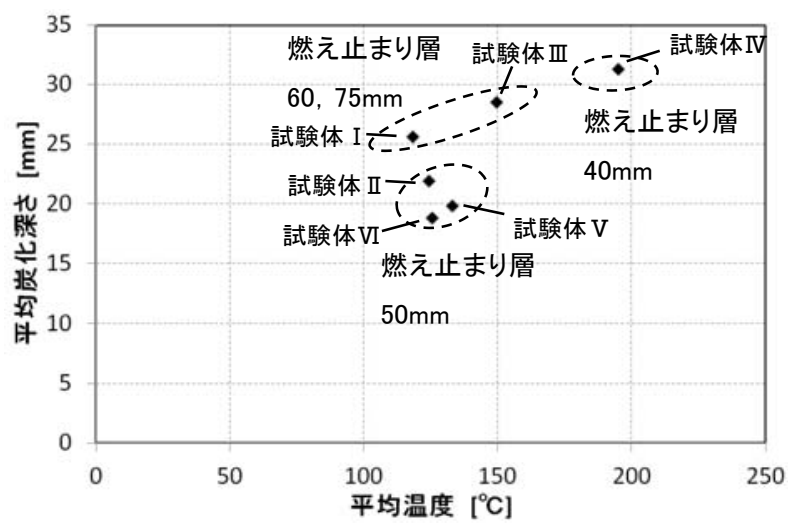

図 17 平均温度と平均炭化深さの関係

\section{5. まとめ}

1 時間耐火構造を目指した様々な断面構成の耐火集成材柱で耐火 試験を実施し，以下の知見を得た。

（1）燃え止まり層厚が同じで荷重支持部寸法が異なる断面（試験 体 I と試験体III)，および断面寸法が同じで荷重支持部の樹種 が異なる断面（試験体 V と試験体VI）の結果から，荷重支持 部と燃え止まり層境界部における温度は熱容量が大きいほど 低くなった。

（2）化粧層厚が $10 \mathrm{~mm}$ である場合, 最も熱的に厳しい隅角部では, 隅角部からの距離 $60 \mathrm{~mm}$ を下回ると急激に温度が上昇した。ま た隅角部からの距離を変数とすることで, 温度上昇の傾向を 確認することができた。一般部においては，燃え止まり層厚 $40 \mathrm{~mm}$ でも最高温度が $150^{\circ} \mathrm{C}$ 程度にとどまった。

（3）炭化深さは，平均值の周辺でピークを有する左右対称な分布 形状となる。ラミナ内部における難燃処理薬剤の含浸分布に 依存していると推測されるが，天然素材でもともとバラッキ の大きい木材に対して，インサイジング処理を施して難燃処 理薬剤を含浸させる手法を用いることでバラツキ幅を制御す ることができ，本手法の有効性が確認できた。

（4）荷重支持部と燃え止まり層境界部における計測点全体の平均 温度と平均炭化深さの関係を確認した。開発した耐火集成材 では, 燃え止まり層 $40 \mathrm{~mm}$ は荷重支持部が炭化しない最低に近 い厚さとなった。

（5）燃え止まり性状には，寸法や樹種といった断面仕様の他に, 加熱停止後の炉内温度の低下曲線も影響した。

\section{参考文献}

1) 大橋宏和，長岡 勉，永盛洋樹，高橋 拡，山本正人，杉田敬太郎，遊佐 秀逸, 大宮喜文, 山田 誠, 齋藤 潔：耐火木造部材の荷重支持部の木材 密度が耐火性能に与える影響, 日本建築学会技術報告集, 第 21 巻, 第 47 号, pp. 151 156, 2015. 2

2) 浅野天仁，松岡祐一，染谷朝幸，永山浩三：ホウ素系薬剂処理 LVL を用い た木質系 2 時間耐火部材の開発, 日本建築学会大会学術講演梗概集（北海 道)，pp. 129-130，2013

3) 景山悠太郎, 長谷見雄二, 夫馬康仁, 原田浩司, 飯島泰男, 板垣直行, 常 世田昌寿 : スギ間伐材を主材料とする木現し耐火構造部材の開発，日本建 築学会大会学術講演梗概集（北陸），pp. 107 108，2010

4) 抱 憲誓, 宮本圭一，西村光太，服部順昭，安藤恵介，石垣弘之，原田寿 郎，上川大輔，宮林正幸，大内富夫：耐火集成材の開発（その 6) ラミナ の部分的薬剂処理により作製したスギ耐火集成材柱の載荷加熱実験，日本 建築学会大会学術講演梗概集（東北），pp. 321～322，2009

5) 抱 憲誓，宮本圭一，西村光太，服部順昭，安藤恵介，原田寿郎，上川大 輔，宮林正幸：耐火集成材の開発（その 16）小断面又ギ耐火集成材柱の載 荷加熱実験および大断面部材との比較, 日本建築学会大会学術講演梗概集 (東海)， pp. 359 360，2012

6) IS0834, Fire-resistance-tests, Elements of building construction, 1999

7) 日本建築学会 : 建築物の火災荷重および設計火災性状指針（案)，pp. 158, 2013

[2016 年 2 月 1 日原稿受理 2016 年 4 月 4 日採用決定］ 